\title{
REKONSTRUKSI FASILITAS PENDIDIKAN PASCA BENCANA GEMPA BUMI TAHUN 2018 DI KABUPATEN SUMBAWA PROVINSI NTB MENGGUNAKAN KONSTRUKSI RISHA
}

\author{
Faiz Sulthan') \\ 1) Kementerian Pekerjaan Umum dan Perumahan Rakyat Republik Indonesia \\ (Jl. Pattimura 20, Kebayoran Baru Jakarta Selatan, Indonesia) \\ e-mail: faiz.sulthan@pu.go.id
}

\begin{abstract}
The Province of West Nusa Tenggara (NTB) suffered a series of earthquakes which began on July 29, 2018 (M6.4) as a foreshock, August 5, 2018 (M7.0) as the first mainshock, 9 August 2018 (M6.2) as aftershocks, and 19 August 2018 which was preceded by M6.3 foreshock and M6.9 second mainshock. This earthquake disaster has caused many casualties. Some casualties were injured by the light damaged to collapsed buildings and infrastructures. Based on Presidential Instruction (INPRES) No.5 of 2018, Ministry of Public Works and Housing (PWH) was assigned to carry out rehabilitations and reconstructions after the earthquake. The areas that had been affected by the earthquakes are Mataram city, North Lombok Regency, West Lombok Regency, Central Lombok Regency, East Lombok Regency, West Sumbawa Regency, and Sumbawa Regency. The Mandate of INPRES No. 5 of 2018, is that the reconstruction process must be carried out using earthquake resistant building technology and in a short time. To answer these tasks and challenges, the Ministry of PWH used the construction of Simple Healthy Instant Houses (Rumah Instan Sederhana Sehat or RISHA), as earthquake resistant building technology that had been developed and owned by the Ministry of PWH.-RISHA construction is not only an earthquake resistant building technology, but also a construction using knock down technology with precast system so that it can be constructed in a relative fast time. This paper discusses the activities of reconstructing educational facilities in Sumbawa Regency, NTB Province using RISHA construction.
\end{abstract}

Key Words: Earthquakes, Earthquake resistant building technology, Reconstruction, RISHA

\section{PENDAHULUAN}

Wilayah Indonesia sangat berpotensi terjadi gempa bumi karena posisinya yang berada di pertemuan tiga lempeng utama dunia, yaitu Eurasia, Indo-Australia dan Pasifik. Selain berada di antara lempeng-lempeng utama dunia, posisi Indonesia terletak di Cincin Api Pasifik (Pacific Ring of Fire) yaitu daerah sepanjang $40.000 \mathrm{~km}$ yang sering mengalami gempa bumi dan letusan gunung berapi di wilayah cekungan Samudra Pasifk.

Provinsi Nusa Tenggara Barat mengalami rangkaian gempa dimulai pada tanggal 29 Juli 2018 (M6,4) sebagai gempa awalan (foreshock), 5 Agustus 2018 (M7,0) sebagai gempa utama (mainshock) pertama, 9 Agustus 2018 (M6,2) sebagai gempa susulan (aftershock) signifikan, serta 19 Agustus 2018 yang didahului foreshock M6,3 dan mainshock kedua M6,9 sepuluh jam setelahnya. Gempa ini telah mengakibatkan korban jiwa yang tidak sedikit. Terdapat korban yang diakibatkan oleh kerusakan infrastruktur berupa bangunan yang mengalami rusak ringan hingga runtuh.
Berdasarkan dampak dari serangkaian peristiwa bencana gempa bumi di Lombok tahun 2018, Presiden Republik Indonesia mengeluarkan Instruksi Presiden (INPRES) Nomor 5 tahun 2018 tentang percepatan Rehabilitasi dan Rekonstruksi Pasca Bencana Gempa Bumi Lombok. Melalui Inpres tersebut, Kementerian Pekerjaan Umum dan Perumahan Rakyat (PUPR) diamanahkan untuk melakukan kegiatan Rehabilitasi dan Rekonstruksi. Lingkup dari kegiatannya adalah melakukan percepatan, dan bertanggung jawab dalam proses pengawasan pelaksanaan rehabilitasi dan rekonstruksi fasilitas pendidikan, fasilitas kesehatan, fasilitas agama, fasilitas penunjang perekonomian, prasarana dasar pasca bencana gempa bumi, serta rumah masyarakat dengan bangunan tahan gempa.

Konstruksi bangunan tahan gempa yang telah ditemukan dan dikembangkan oleh Kementerian PUPR salah satunya adalah konstruksi Rumah Instan Sederhana Sehat (RISHA). RISHA sebagai bentuk rekayasa teknologi knock down yang digunakan pada bangunan rumah tinggal sederhana 
sehat, telah sesuai dengan Kepmen Kimpraswil No. 403/KPTS/M/2003 tentang Pedoman Teknis Rumah Sederhana Sehat. Teknologi RISHA yang menggunakan bahan beton bertulang dan tidak banyak mengkonsumsi material dari alam, sangat layak dikembangkan karena ramah lingkungan dan memenuhi standar (PUSKIM, 2004).

Berdasarkan hasil pengujian (uji tekan, uji geser, uji lentur, dan uji bangunan skala penuh pada bangunan RISHA) yang telah dilakukan di laboratorium dan lapangan, menunjukkan bahwa bangunan RISHA memiliki keandalan terhadap beban gempa sampai dengan daerah KDS D (yaitu daerah beresiko gempa tinggi di Indonesia). RISHA telah dipakai di beberapa daerah seperti di Nanggroe Aceh Darusalam (NAD), Nias, Jawa Barat, Kepulauan Riau, Sumatera Barat, Bengkulu, Lampung, Bangka Belitung, Jambi, Yogyakarta, Jawa Tengah, Bali, NTT, dan NTB. Pasca gempa Lombok tahun 2018, konstruksi RISHA yang dibangun di NTB pada tahun 2010 terbukti tahan terhadap gempa seperti dapat dilihat pada Gambar 1.

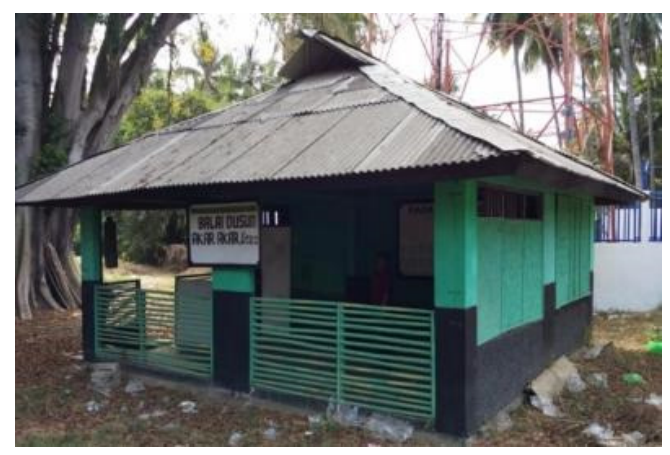

(a)

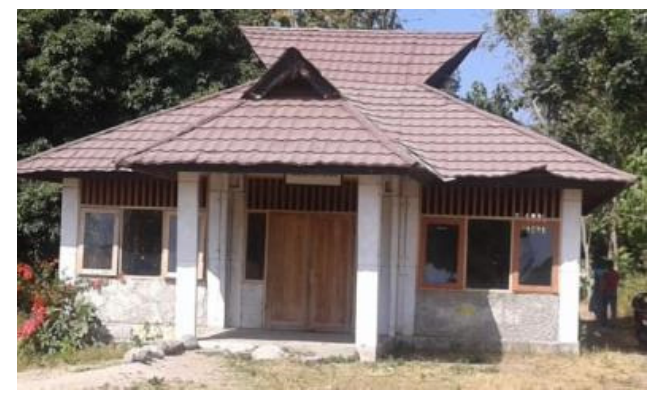

(b)

Gambar 1. Konstruksi RISHA yang bertahan pasca Gempa Lombok tahun 2018, (a) Balai Dusun Akar-Akar Utara Kabupaten Lombok Utara, (b) Sekolah Adat Bayan Kabupaten Lombok Utara (Sumber: Dokumen Pribadi)

Wilayah yang terdampak gempa Lombok tahun 2018 meliputi Kota Mataram, Kabupaten Lombok
Utara, Kabupaten Lombok Barat, Kabupaten Lombok Tengah, Kabupaten Lombok Timur, Kabupaten Sumbawa Barat, dan Kabupaten Sumbawa. Berdasarkan penjabaran sebelumnya, pada makalah ini dibahas mengenai rekonstruksi fasilitas pendidikan di Kabupaten Sumbawa Provinsi Nusa Tenggara Barat menggunakan Konstruksi RISHA.

\section{GAMBARAN UMUM}

\subsection{Kronologi Gempa Lombok}

Kronologi gempa bumi Lombok dan Sumbawa seperti pada Gambar 2 dimulai pada hari Minggu, tanggal 29 Juli 2018 pukul 05.47 WIB dengan kekuatan M6,4. Gempa tersebut terletak pada koordinat 8,35 LS dan 116,5 BT, Berdasarkan informasi dari BMKG, gempa Lombok 29 Juli 2018 memiliki intensitas IV pada Skala Intensitas Gempa BMKG (SIG-BMKG) setara dengan VI-VIII MMI. Gempa tersebut disusul dengan gempa susulan yang hingga pukul 22.00 WIB di hari yang sama, telah terjadi 213 kali gempa susulan. Gempa ini kemudian diketahui sebagai foreshock dari gempa utama yang terjadi pada hari Minggu tanggal 5 Agustus 2018 pukul 18.46 WIB, dengan magnitudo 7 pada 8,37 LS dan 116,48 BT yang memberikan dampak yang luas. Empat belas hari setelahnya, pada tanggal 19 Agustus 2018 terjadi kembali gempa pada segmen di sisi timur, dimulai dengan gempa magnitudo 6,3 dan disusul oleh gempa dengan magnitudo 6,9. Pasca rangkaian gempa ini, BNPB mencatat 560 jiwa penduduk meninggal dunia, 396.032 jiwa penduduk mengungsi, dan 83.392 rumah rusak (PusGen, 2018).

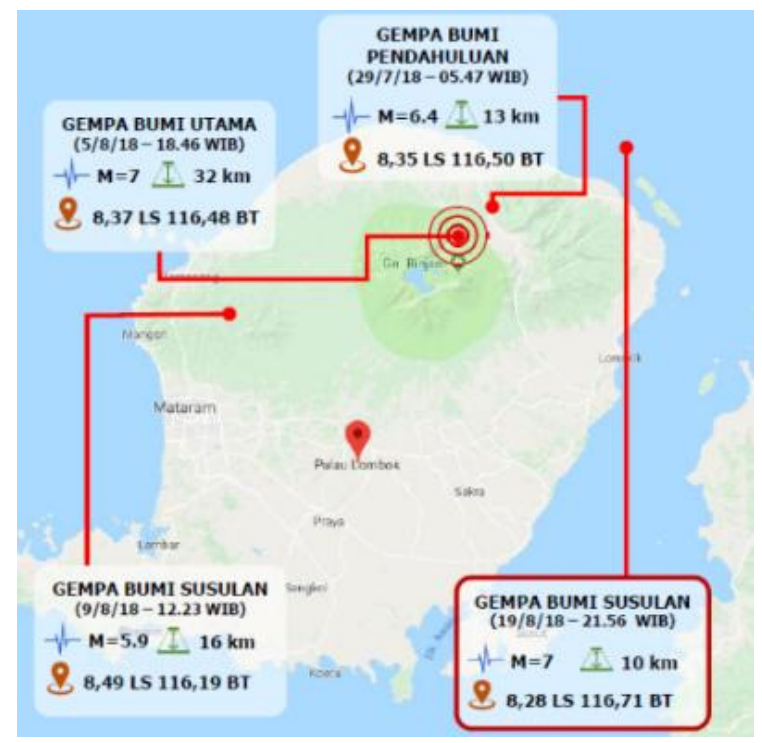

Gambar 2. Kronologi gempa Lombok tahun 2018 (PusGen, 2018) 


\subsection{Kabupaten Sumbawa}

Pulau Sumbawa adalah pulau yang terletak di Provinsi Nusa Tenggara Barat. Letaknya adalah di bagian timur Provinsi NTB seperti pada Gambar 3. Pulau ini berseberangan dengan Pulau Lombok yang dibatasi oleh Selat Alas. Memiliki luas $14.386 \mathrm{~km}^{2}$ menjadikan Pulau Sumbawa pulau terbesar di Provinsi NTB. Pulau Sumbawa terdiri dari empat Kabupaten dan satu kota yaitu Kabupaten Sumbawa, Sumbawa Barat, Dompu, Bima, dan Kota Bima. Gempa Lombok tahun 2018 berdampak pada daerah bagian barat Pulau Sumbawa, yaitu Kabupaten Sumbawa dan Sumbawa Barat.

Dari data katalog gempa bumi signifikan dan merusak BMKG hingga tahun 2009 (BMKG, 2010) terdapat beberapa gempa bumi yang pernah dirasakan di Pulau Sumbawa antara lain gempa bumi yang terjadi 2 November 1954, 19 Agustus 1977, 7 Oktober 1977, 10 April 1978, 30 Mei 1979, 11 Maret 1982, 1 Desember 2006, 25 November 2007 dan 8 November 2009.

Pulau Sumbawa dan sekitarnya merupakan bagian dari kerangka sistem tektonik Indonesia. Daerah ini termasuk dalam jalur pegunungan Mediteranian yang lokasinya berdekatan dengan zona tumbukan lempeng (plate collision). Pertemuan kedua lempeng ini bersifat konvergen, di mana keduanya bertumbukan dan lempeng Pergerakan lempeng Indo-Australia terhadap lempeng Eurasia diperkirakan memiliki kecepatan 7 cm per tahun (DeMets, dkk., 1994).

Gambaran kerangka tektonik dan kegempaan di atas cukup memberikan gambaran yang menyeluruh bahwa daerah Sumbawa dan sekitarnya merupakan Kawasan rawan terhadap bencana gempabumi dan bencana yang mengikutinya (Sunardi, dkk., 2012).

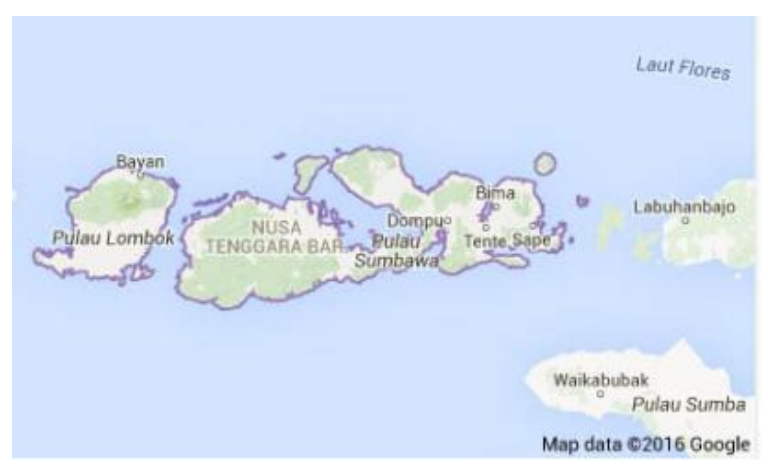

Gambar 3. Peta Provinsi Nusa Tenggara Barat (PusGen, 2018)

\subsection{Fasilitas Pendidikan Terdampak}

Fasilitas pendidikan yang terdampak gempa bumi dan ditangani Kementerian PUPR di Kabupaten Sumbawa total berjumlah 132 fasilitas pendidikan, yang terdiri dari 7 TK/PAUD, 110 sekolah dasar (SD), 13 sekolah menengah pertama
(SMP), dan 2 sekolah menengah atas (SMA). Penanganan yang dilakukan terhadap fasilitas pendidikan yang terdampak tersebut adalah berdasarkan hasil verifikasi bangunan yang dilakukan pasca terjadinya gempa bumi. Klasifikasi tipe kerusakan bangunan terdampak terdiri dari penanganan rusak ringan (RR), rusak sedang (RS), dan rusak berat (RB). Penanganan rusak sedang dan rusak ringan cukup dilakukan rehabilitasi pada bangunan yang mengalami kerusakan, sedangkan untuk penangan rusak berat, bangunan yang mengalami rusak berat dilakukan rekonstruksi yaitu bangunan lama yang terdampak gempa dirobohkan kemudian dibangun baru dengan teknologi tahan gempa RISHA. Pengklasifikasian untuk rusak berat adalah berdasarkan hasil verifikasi pada bangunan yang mengalami kerusakan dengan kriteria dinding pemikul beban atau kolom mengalami kerusakan terbelah hingga roboh, 50\% elemen struktur utama mengalami kerusakan, dan bangunan sudah membahayakan.

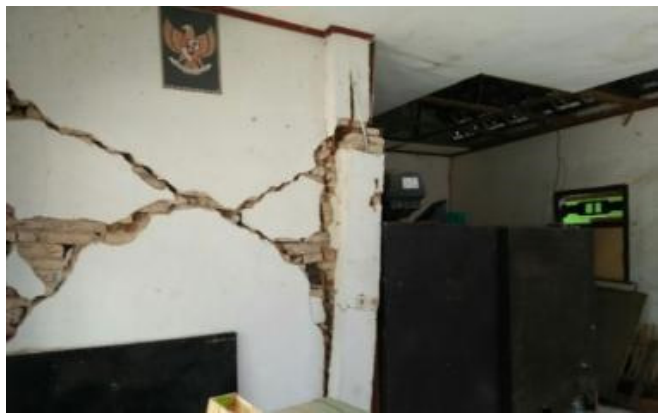

Gambar 4. Gedung yang mengalami rusak berat (Sumber: Dokumen Pribadi)

Untuk pengklasifikasian rusak sedang, kriterianya adalah struktur mengalami retak besar pada dinding; retak menyebar luas di banyak tempat, seperti pada dinding pemikul beban dan kolom, kemampuan struktur untuk memikul beban sudah sebagian berkurang, 30\% s.d 50\% komponen struktur utama mengalami kerusakan, dan retak dengan lebar celah lebih besar dari $6 \mathrm{~mm}$.

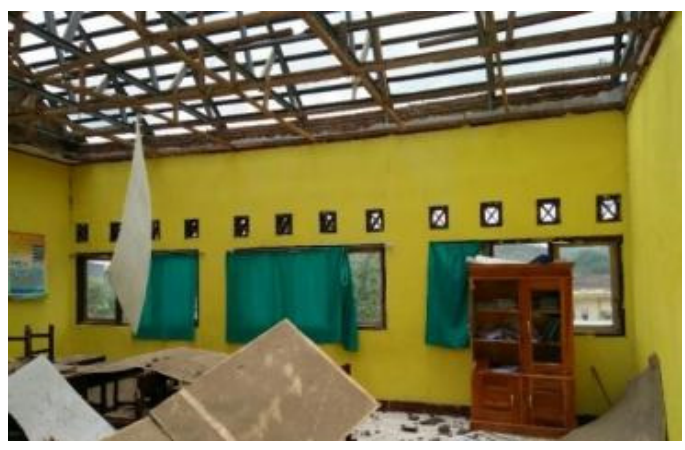

Gambar 5. Gedung yang mengalami rusak sedang (Sumber: Dokumen Pribadi) 
Kriteria rusak ringan bangunan dapat ditentukan dengan menganalisis kondisi bangunan secara langsung. Adapun kriteria bangunan tersebut diidentifikasi mengalami kerusakan ringan adalah mengalami kondisi retak kecil (lebar celah antara 0,75 $\mathrm{mm}$ hingga $6 \mathrm{~mm}$ ) pada dinding, plester berjatuhan mencakup luas yang besar, kurang dari $30 \%$ komponen struktur utama mengalami kerusakan, kerusakan bagian-bagian non-struktur, dan kemampuan struktur untuk memikul beban tidak banyak berkurang.

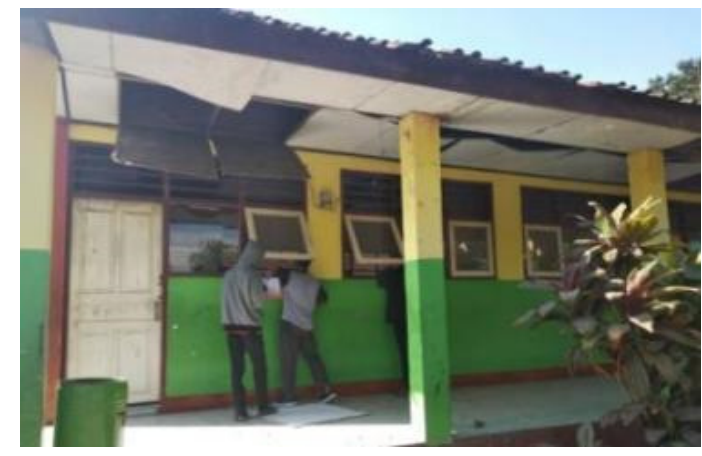

Gambar 6. Gedung yang mengalami rusak ringan (Sumber: Dokumen Pribadi)

Berdasarkan hasil verifikasi tipe kerusakan bangunan, bangunan fasilitas pendidikan yang terdampak di Kabupaten Sumbawa dapat dilihat seperti pada Tabel 1.

Tabel 1. Hasil verifikasi tipe kerusakan fasilitas pendidikan di Kabupaten Sumbawa

\begin{tabular}{ccccc}
\hline Fasilitas & \multicolumn{3}{c}{ Tipe kerusakan } & Jumlah \\
\cline { 2 - 4 } Pendidikan & RB & RS & RR & \\
\hline TK/PAUD & 1 & 1 & 5 & 7 \\
\hline SD & 17 & 21 & 72 & 110 \\
\hline SMP & 3 & 2 & 8 & 13 \\
\hline SMA & - & - & 2 & 2 \\
\hline
\end{tabular}

\subsection{Konstruksi RISHA}

Kementerian Pekerjaan Umum Perumahan Rakyat (PUPR) melalui Pusat Penelitan dan Pengembangan (Puslitbang) Bidang Perumahan dan Permukiman telah menciptakan sebuah teknologi konstruksi Rumah Instan Sederhana Sehat (RISHA). RISHA-merupakan teknologi konstruksi rumah layak huni dan terjangkau dengan sistem knock down. Teknologi ini dapat dibangun secara bertahap dan waktu yang diperlukan untuk proses pembangunan setiap modul berukuran 3x3 m (Gambar 7) adalah 24 jam dengan 3 orang pekerja. Setiap modul memiliki tiga jenis komponen panel struktur yakni Panel P1, P2 dan P3 yang memiliki sifat fleksibel dan efisien dalam konsumsi bahan bangunan. Beberapa keunggulan RISHA antara lain lebih cepat, lebih murah, lebih ramah lingkungan, lebih tahan gempa, moveable, lebih ringan dan dapat dimodifikasi (PUSKIM, 2015).

Komponen struktural adalah komponen yang mendukung berdirinya bangunan. Jika komponen struktural dihilangkan, maka bangunan akan mengalami kerusakan dan tidak dapat berfungsi sebagai mana mestinya. Komponen struktural dibagi menjadi tiga sistem, yaitu: sistem pondasi, sistem rangka, dan sistem atap. Pada teknologi RISHA, komponen struktural utama terdiri dari 3 panel, yaitu: panel struktural tipe 1 (P1), panel struktural tipe 2 (P2), dan panel simpul atau penyambung (P3) seperti dapat dilihat pada Gambar 8. Ketiga panel RISHA tersebut merupakan bagian dari sistem rangka (PUSKIM, 2015).

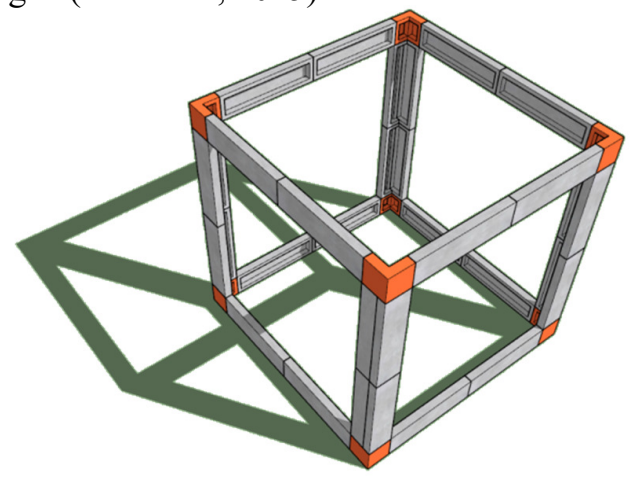

Gambar 7. Modul panel RISHA 3x3 m (PUSKIM, 2015)

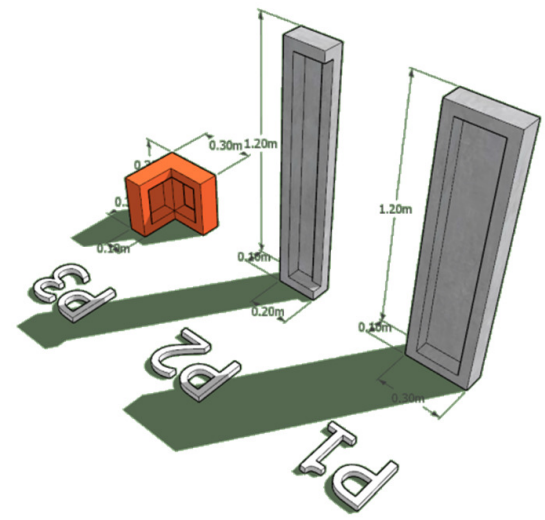

Gambar 8. Komponen struktural utama panel RISHA (PUSKIM, 2015)

\section{PELAKSANAAN KEGIATAN}

\subsection{Pembersihan Lahan}

Proses rekonstruksi dilakukan pada fasilitas pendidikan yang diverifikasi sebagai bangunan rusak berat $(\mathrm{RB})$. Tahap awal yang dilakukan pada bangunan rusak berat adalah perobohan bangunan tersebut dengan alat berat. Perobohan bangunan lama bertujuan untuk membersihkan lokasi sehingga lahan siap untuk dibangun bangunan baru. Setelah lahan telah bersih maka dibangun Ruang Kelas Belajar Sementara (RKBS). 


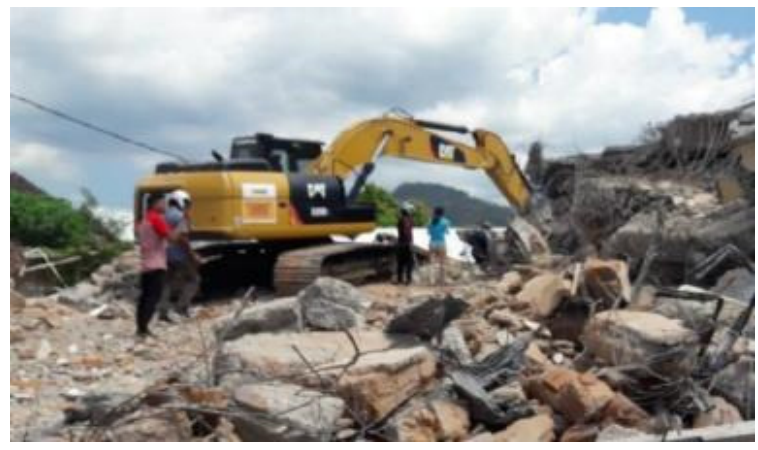

Gambar 9. Proses pembersihan lahan (Sumber: Dokumen Pribadi)

\subsection{Pembangunan Ruang Kelas Belajar Sementara (RKBS)}

Ruang Kelas Belajar Sementara (RKBS) dibangun untuk keperluan keberlangsungan proses belajar mengajar selama proses rekonstruksi dilakukan. Meskipun konstruksi RISHA dapat dibangun dengan waktu yang relatif cepat, namun proses belajar siswa tidak boleh terhenti. RKBS dibangun dengan bangunan sementara menggunakan konstruksi baja ringan dengan dinding kalsiboard dan beratapkan seng. Lokasi pembangunan RKBS dibangun pada lahan kosong yang tidak digunakan untuk rencana pembangunan bangunan permanen. Dengan demikian bangunan RKBS tidak mengganggu pembangunan bangunan permanen. Kepemilikan juga diserah terimakan kepada pihak sekolah, sehingga tidak perlu dibongkar dan dapat dimanfaatkan pihak sekolah untuk keperluan lain. Proses pembuatan RKBS dapat dilihat seperti pada Gambar 10.

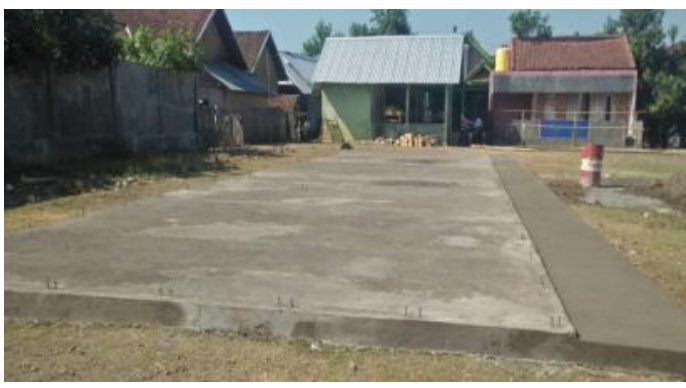

(a)

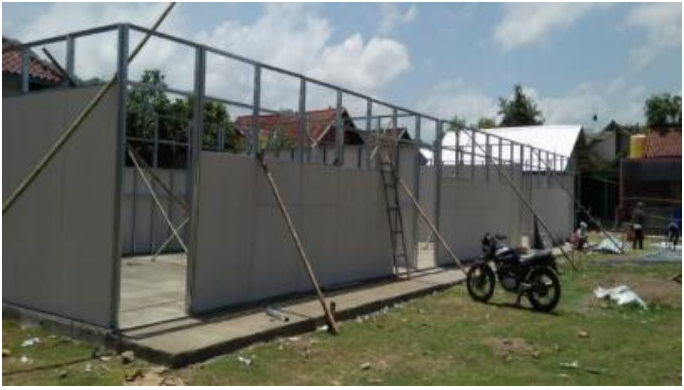

(b)

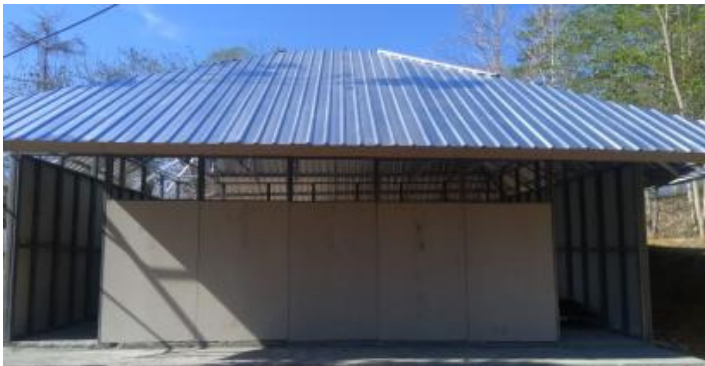

(c)

Gambar 10. Pembangunan Ruang Kelas Belajar Sementara (RKBS): (a) Pembuatan lantai dasar, (b) Pembuatan konstruksi rangka baja dan dinding kalsiboard, (c)

Pemasangan atap seng (Sumber: Dokumen Pribadi)

\subsection{Pembangunan Ruang Kelas Belajar Permanen (RKBP)}

Ruang Kelas Belajar Permanen (RKBP) harus dibangun dengan konstruksi tahan gempa dan dengan waktu yang singkat, maka digunakanlah konstruksi RISHA. Untuk panel RISHA yang biasanya digunakan untuk bangunan rumah tinggal, dilakukan modifikasi sehingga dapat mengakomodir ruang belajar yang sesuai standar. Desain bangunan sekolah yang dibangun dengan konstruksi RISHA dapat dilihat pada Gambar 11.
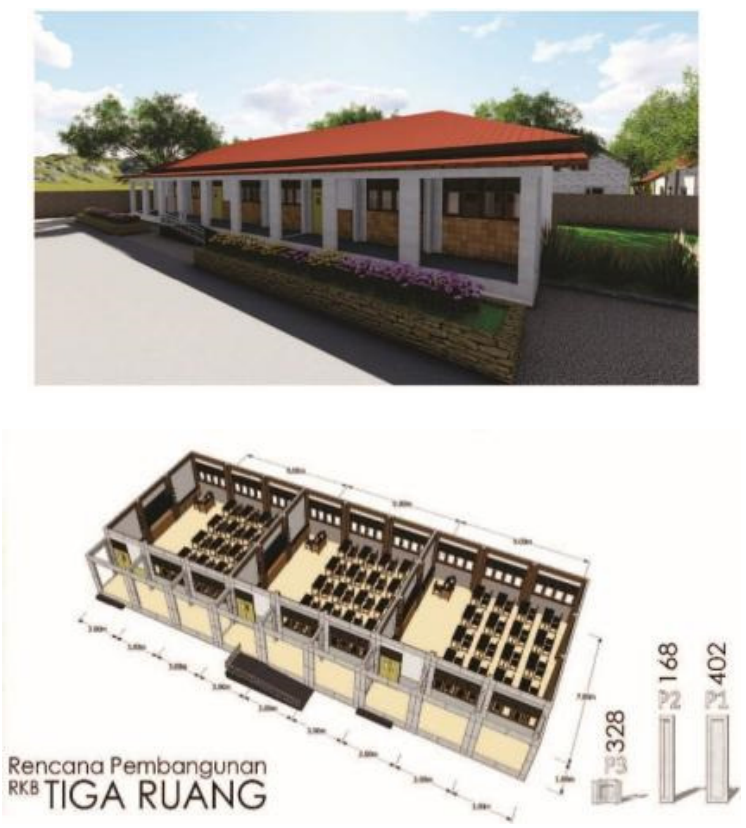

Gambar 11. Desain RISHA untuk bangunan sekolah (Sumber: Dokumen Pribadi)

Tahapan awal pembangunan RKBP menggunakan konstruksi RISHA adalah dengan pembuatan pondasi setempat. Kemudian, pondasi 
setempat dihubungkan dengan panel penyambung P3 menggunakan angkur, dan dirangkai dengan panel P1 sebagai balok sloof seperti pada Gambar 12.

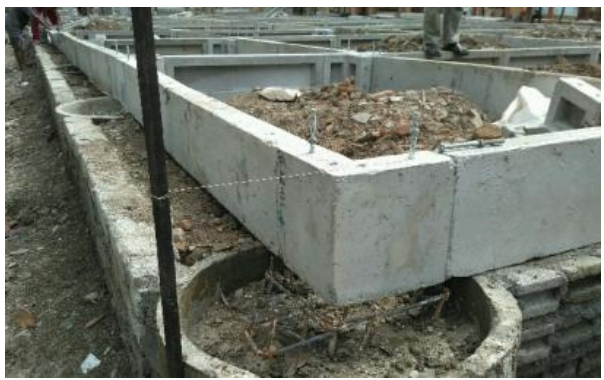

Gambar 12. Konstruksi pondasi setempat RKBP (Sumber: Dokumen Pribadi)

Tahapan selanjutnya adalah pembangunan struktur rangka bangunan, Panel P1 dan P2 yang digabung sehingga membentuk penampang plus (+). Untuk menambah elevasi ruang, maka sambungan antara P1 ke bagian atasnya diberi panel penyambung P3, dan di bagian paling atas diberi double P3. Dengan konstruksi seperti ini, maka ruangan RKBP mempunyai ketinggian plafon hingga 3,3 m seperti dapat dilihat pada Gambar 13.

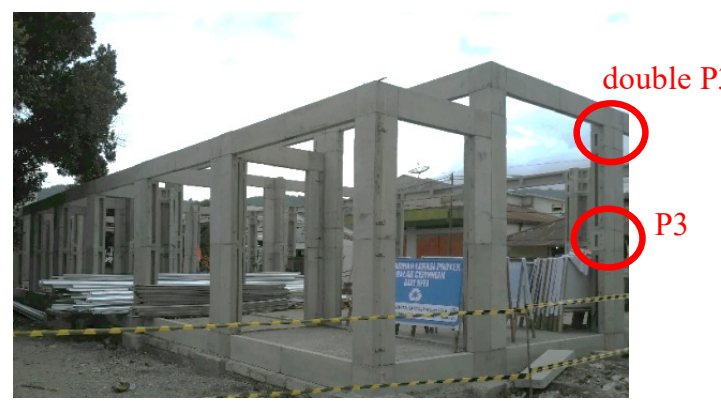

Gambar 13. Konstruksi rangka kolom-ring balok RKBP (Sumber: Dokumen Pribadi)

Tahapan akhir pembangunan ruang kelas belajar permanen menggunakan konstruksi RISHA adalah pemasangan penutup atap, dinding, dan finishing. Konstruksi atap menggunakan material yang ringan yaitu rangka baja ringan dengan penutup atap spandek, sementara bagian dinding menggunakan pasangan bata biasa seperti pada Gambar 14 .

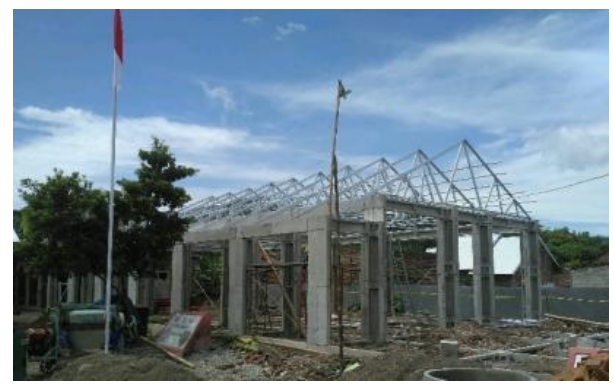

(a)

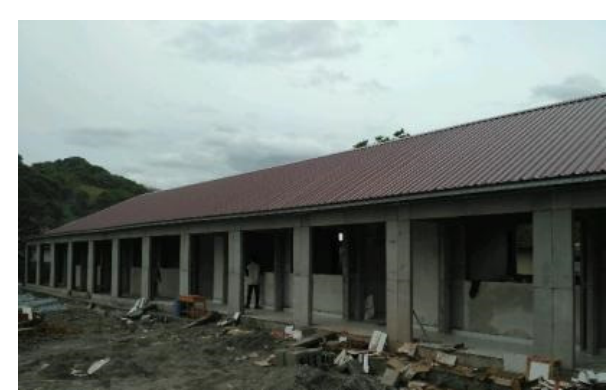

(b)

Gambar 14. Kemajuan pekerjaan penyelesaian RKBP (Sumber: Dokumen Pribadi)

\section{HASIL DAN PEMBAHASAN}

Proses pekerjaan rekonstruksi fasilitas pendidikan menggunakan konstruksi RISHA dari pekerjaan pondasi hingga finishing untuk satu sekolah di Kabupaten Sumbawa membutuhkan waktu rata-rata satu hingga dua bulan, yaitu dari bulan Januari hingga Maret 2019. Lamanya pekerjaan tergantung pada jumlah ruang kelas belajar permanen (RKBP) dalam satu sekolah tersebut dan lokasi sekolah seperti dapat dilihat pada Tabel 2. Sistem pekerjaan yang dilakukan yaitu menggunakan penyedia jasa kontraktor. Proses yang cukup memakan waktu adalah pencetakan panel RISHA yang dikerjakan di workshop, dan proses pekerjaan finishing seperti pemasangan kusen jendela, pintu, plafon, rangka atap, dan pengecetan. Fasilitas pendidikan yang telah selesai dikonstruksi menggunakan teknologi RISHA dapat dilihat pada Gambar 15 dan 16.

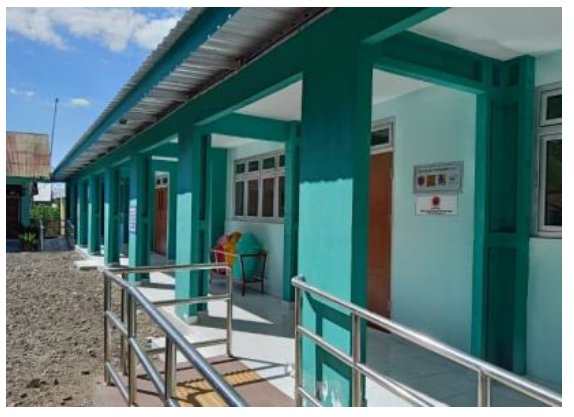

Gambar 15. SDN Mapin Beru (Sumber: Dok. Pribadi)

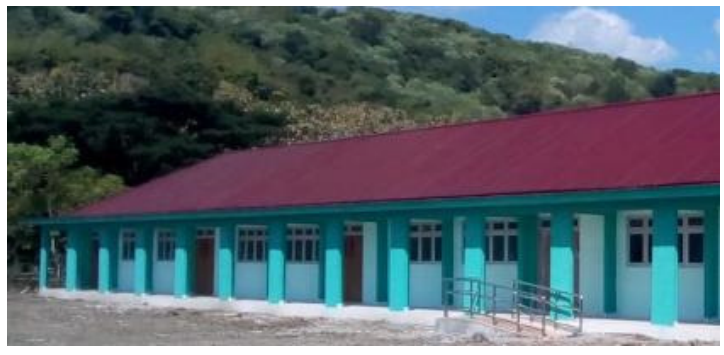

Gambar 16. SLBN 1 Alas (Sumber: Dokumen Pribadi) 
Tabel 2. Waktu pelaksanaan pekerjaan fasilitas pendidikan dengan konstruksi RISHA (Sumber: Dokumen Pribadi)

\begin{tabular}{clcc}
\hline NO & Fasilitas Pendidikan & $\begin{array}{c}\text { Jumlah } \\
\text { RKBP }\end{array}$ & $\begin{array}{c}\text { Waktu } \\
\text { (Bulan) }\end{array}$ \\
\hline $\mathbf{1}$ & SDN 1 Alas & $7+1 \mathrm{wc}$ & 2,0 \\
\hline $\mathbf{2}$ & SDN 7 Alas & 13 & 2,0 \\
\hline $\mathbf{3}$ & SDN 5 Alas & $8+1 \mathrm{wc}$ & 2,0 \\
\hline $\mathbf{4}$ & SDN Marenteh Beru & $1 \mathrm{wc}$ & 1,0 \\
\hline $\mathbf{5}$ & SDN 8 Alas & $6+1 \mathrm{wc}$ & 2,0 \\
\hline $\mathbf{6}$ & SDN 4 Alas & $1 \mathrm{wc}$ & 1,0 \\
\hline $\mathbf{7}$ & SDN Labuhan Alas & 7 & 2,0 \\
\hline $\mathbf{8}$ & SDN Labuhan Mapin & $7+1 \mathrm{wc}$ & 2,0 \\
\hline $\mathbf{9}$ & SDN Mapin Beru & $4+1 \mathrm{wc}$ & 1,5 \\
\hline $\mathbf{1 0}$ & SDN 3 Gontar & $8+1 \mathrm{wc}$ & 2,0 \\
\hline $\mathbf{1 1}$ & SDN Hijrah & 4 & 1,5 \\
\hline $\mathbf{1 2}$ & SDN Mapin Kebak & 6 & 2,0 \\
\hline $\mathbf{1 3}$ & SDN Gelampar & $4+1 \mathrm{wc}$ & 1,5 \\
\hline $\mathbf{1 4}$ & SDN Ai Jati & $7+1 \mathrm{wc}$ & 2,0 \\
\hline $\mathbf{1 5}$ & SDN 3 Alas & 4 & 1,5 \\
\hline $\mathbf{1 6}$ & SDN 10 Alas & $4+1 \mathrm{wc}$ & 1,5 \\
\hline $\mathbf{1 7}$ & SLBN Alas & $13+1 \mathrm{wc}$ & 2,0 \\
\hline $\mathbf{1 8}$ & SMPN 1 Alas & $8+1 \mathrm{twc}$ & 2,0 \\
\hline $\mathbf{1 9}$ & SMPN 3 Alas & 9 & 2,0 \\
\hline $\mathbf{2 0}$ & SMPN 1 Alas Barat & 5 & 1,5 \\
\hline $\mathbf{2 1}$ & Tk Tazkiah & $1 \mathrm{wc}$ & 1,0 \\
\hline $\boldsymbol{*}$ : & &
\end{tabular}

*wc: unit toilet

Kebutuhan masyarakat di NTB adalah konstruksi bangunan tahan gempa yang dapat dikonstruksi dengan cepat, mengingat di sebagian daerah di NTB ini merupakan daerah rawan gempa. Penggunaan konstruksi RISHA yang dibangun pada tahun 2010 dan pasca gempa NTB tahun 2018 tidak terjadi kerusakan merupakan pemecahan masalah keselamatan bangunan di provinsi NTB. Kecepatan konstruksi dari teknologi RISHA juga menjawab tantangan untuk proses rekonstruksi yang membutuhkan waktu cepat, sehingga kegiatan (proses) pendidikan kembali pulih.

\section{KESIMPULAN}

Berdasarkan uraian pada makalah ini, kesimpulan yang dapat diperoleh adalah sebagai berikut:

1. Konstruksi RISHA merupakan teknologi bangunan tahan gempa yang bukan hanya teruji di Laboratorium namun juga di lapangan yang dibuktikan dengan masih berdirinya Gedung Balai Dusun Akar-Akar Utara Kabupaten Lombok Utara, dan Sekolah Adat Bayan Kabupaten Lombok Utara pasca gempa bumi Lombok tahun 2018.
2. Fasilitas pendidikan yang terdampak dan ditangani Kementerian PUPR di Kabupaten Sumbawa pasca gempa bumi Lombok tahun 2018 total berjumlah 132 fasilitas pendidikan, yang terdiri dari 7 TK/PAUD, 110 sekolah dasar (SD), 13 sekolah menengah pertama (SMP), dan 2 sekolah menengah atas (SMA).

3. Berdasarkan hasil verifikasi tingkat kerusakan, terdapat 1 PAUD/TK, 17 sekolah dasar (SD), dan 3 sekolah menengah pertama (SMP) yang mengalami rusak berat (RB).

4. Proses pekerjaan rekonstruksi fasilitas pendidikan menggunakan konstruksi RISHA dari pekerjaan pondasi hingga finishing untuk satu sekolah di Kabupaten Sumbawa membutuhkan waktu rata-rata satu hingga dua bulan. Lamanya pekerjaan tergantung banyaknya ruang kelas belajar permanen (RKBP) yang dibangun dalam satu sekolah dan kemudahan akses ke lokasi.

5. Konstruksi RISHA menjawab permasalahan kebutuhan teknologi tahan gempa yang dapat dikonstruksi cepat untuk penanganan rekonstruksi di wilayah terdampak gempa bumi.

\section{DAFTAR PUSTAKA}

DeMets, C., R.G. Gordon, D.F. Argus, \& S. Stei. (1994). Effect of Recent to the geomagnetics reversal time scale on estimates of current plate motions. Revisions Geophysical Research Letter, 21, 2191-2194.

Pusat Studi Gempa Nasional-PusGen. (2018). Kajian Rangkaian Gempa Lombok Provinsi Nusa Tenggara Barat. Badan Penelitian dan Pengembangan Kementerian Pekerjaan Umum dan Perumahan Rakyat. Bandung.

Pustlitbang Permukiman-PUSKIM. (2004). Hasil Uji Struktur Bangunan RISHA Skala Penuh terhadap Beban Lateral Gempa. Badan Penelitian dan Pengembangan Kementerian Pekerjaan Umum dan Perumahan Rakyat. Bandung.

Pustlitbang Perumahan dan Permukiman-PUSKIM. (2015). Modul RISHA (Rumah Instan Sederhana Sehat). Badan Penelitian dan Pengembangan Kementerian Pekerjaan Umum dan Perumahan Rakyat. Bandung.

Sub Bidang Mitigasi Gempabumi. (2010). Katalog gempabumi signifikan dan merusak 1821- 2009. BMKG.

Sunardi, B., Daryono, Arifin, J., Susilanto, P., Ngadmanto, D., Nurdiyanto, B., dan Sulastri. (2012). Kajian Potensi Bahaya Gempabumi Daerah Sumbawa Berdasarkan Efek Tapak Lokal. Jurnal Meteorologi dan Geofisika. Vol. 13 No. 2:131-137 